Western University

Scholarship@Western

Aboriginal Policy Research Consortium International (APRCi)

$8-2010$

\title{
The Multifunctional Transition in Australia's Tropical Savannas: the Emergence of Consumption, Protection and Indigenous Values
}

John Holmes

Follow this and additional works at: https://ir.lib.uwo.ca/aprci

Part of the Nature and Society Relations Commons

Citation of this paper:

Holmes, John, "The Multifunctional Transition in Australia's Tropical Savannas: the Emergence of Consumption, Protection and Indigenous Values" (2010). Aboriginal Policy Research Consortium International (APRCi). 200.

https://ir.lib.uwo.ca/aprci/200 


\title{
The Multifunctional Transition in Australia's Tropical Savannas: the Emergence of Consumption, Protection and Indigenous Values
}

\author{
JOHN HOLMES
}

School of Geography, Planning and Environmental Management, The University of Queensland, 4072, Australia. Email: j.holmes@uq.edu.au

Received 31 August 2008; Revised 10 February 2009; Accepted 14 September 2009

\begin{abstract}
As elsewhere in affluent, western nations, the direction, complexity and pace of rural change in Australia can be conceptualised as a multifunctional transition in which a variable mix of consumption and protection values has emerged, contesting the former dominance of production values, and leading to greater complexity and heterogeneity in rural occupance at all scales. This transition has been explored in accessible, high-amenity landscapes driven by enhanced consumption values. Less attention has been directed to remote, marginal lands where a flimsy mode of productivist occupance can, in part, be displaced by alternative modes with the transitions being facilitated by low transfer costs. Such is the case in Australia's northern tropical savannas where an extensive mode of pastoral occupance is selectively displaced by alternative consumption, protection and Indigenous values. This transition towards multifunctional occupance is most readily documented by mapping changes in land tenure and ownership over the last three decades. Tenure changes have been accompanied by new regimes of property rights and land ownership, including: native titles derived from common law; non-transferable, common-property Aboriginal freehold tenures; transfers of pastoral leases to Indigenous and conservation interests; expansion of conservation lands under public tenures; and revisions of the rights and duties of pastoral lessees. Future occupance scenarios remain unclear, given the sensitivity of this frontier zone to national and global driving forces.
\end{abstract}

KEY WORDS multifunctionality; multifunctional transition; rural occupance; land tenure; Indigenous tenures; tropical savannas; North Australia; Cape York Peninsula

\section{Conceptualising rural change as a transition to multifunctionality}

Multifunctionality seems poised to succeed postproductivism as a framework within which to interrogate contemporary rural dynamics ... Increasingly ... demands on rural areas extend beyond production and include demands for the provision of ecosystem services, amenities and aesthetics, and preservation of cultural landscapes. (McCarthy, 2005, 774).

It is difficult to draw together a firm set of conclusions from the scenarios presented. They suggest that in the next decade northern pastoralists will be affected by developments in the rights of Aboriginals, increased pressures from an expanding tourist industry, a rapidly developing mining industry and, 
above all else, a growing public concern that our remaining natural vegetation should be carefully husbanded... It is possible that increasing numbers of Australians will become concerned about finding ways which will allow us all to use pastoral lands and maintain their condition. It is unlikely that they will become very concerned about the well-being of a few pastoralists. (Young, 1981, 158).

As indicated in recent publications, I endorse McCarthy's broad interpretation of multifunctionality as the core dynamic driving rural change. I have sought to articulate, interpret and test the utility of the multifunctionality concept in a national overview of regionally differentiated rural change in Australia, arguing that ... 'The direction, complexity and pace of rural change in affluent, western societies can be conceptualized as a multifunctional transition in which a variable mix of consumption and protection values has emerged, contesting the former dominance of production values, and leading to greater complexity and heterogeneity in rural occupance at all scales.' (Holmes, 2006, 142).

Of necessity this approach is incompatible with narrow interpretations of multifunctionality as an attribute specific only to farming systems. As the central concept underpinning the shift in the agricultural support policies of the European Union, multifunctionality has been preemptively conceived as an attribute uniquely associated with 'traditional' European farming systems, a stance strongly criticised by rural researchers (Lowe et al., 2002; Potter and Burney, 2002; Holmes, 2006) as well as by international and national policy organisations (OECD, 2001). Multifunctionality lends itself to translation into a policy-oriented doctrine, most notably in providing a rationale for the new strategies in support of agriculture within the European Union. This doctrine could more appropriately be described as 'neoagrarianism', reliant on a supposition of agricultural exceptionalism and anchored to the multifunctionality concept. For comprehensive reviews of post-productivism and agricultural multifunctionality, see Wilson (2001; 2007).

Multifunctionality is increasingly recognised and valued as an attribute of technologies, production systems and institutions as well as landscapes and natural resources. It has become a core marketing attribute tied to current technol- ogy, including digital phones, workstations and washing machines. It is implicitly valued as an attribute of natural resources, including forests, catchments, streams, estuaries, beaches and so on. It is explicitly, often vigorously, asserted as an attribute of production systems and institutions, including agriculture, forestry, catchment management, ecotourism and the federal lands in western United States. The concept has been systematically explored in de Groot's (2005) functional analysis of rural landscapes in Germany. Based upon assessments of the ecological, socio-cultural and economic values of defined land units, de Groot constructs a decision support system towards conflict resolution and in support of planning for sustainable multifunctional landscapes. In pursuit of similar goals, Ling et al. (2007) have assessed proposals for restructuring an English post-industrial landscape, tied to the historical, ecological, communitarian, economic and aesthetic values of individual land units. These micro-appraisals of current landscape values are consistent with the broadscale interpretation of rural change and of the forces driving change, cited above.

It is self-evident that a transition towards multifunctional occupance will emerge in areas where production values are no longer preeminent. This may be the result of an upsurge in consumption and protection values, as in peri-metropolitan and high-amenity 'treechange' locales, as shown in a multiplicity of publications cited in Holmes (2006). Less well documented is the transition occurring on remote, marginal or submarginal lands where a flimsy mode of productivist occupance is readily displaced by alternative modes. Because of limited investment in landscape transformation, marginal lands commonly retain high conservation value, with any transition being facilitated by low transfer costs. As shown later, this transition often triggers the entry of a distinctive nature-oriented set of low-cost consumption activities. One further distinctive outcome is the capacity to support the aspirations of Indigenous peoples towards legal recognition of traditional resource rights. Thus complex multifunctionality emerges at the opposite extremes in the intensity of demand on rural space. In this paper, I explore the 'low intensity' extreme using evidence on changing land tenures, property rights, land ownership and land use in the tropical savanna bioclimatic zone, appropriately described as Australia's northern frontier. 


\section{The tropical savannas: an enduring colonial frontier}

\section{Goals of national development}

The Northern Territory is one of Australia's most challenging frontiers. Unexplored and unexploited, its resources await development. (Commonwealth of Australia, 1959).

Over most of the twentieth century Australia's tropical north has been seen as a persistent, enticing, frustrating national development challenge. There has been a succession of agenda-setting governmental committees and publications, such as Northern Australia: Task for a Nation (Australian Institute of Political Science, 1954), backed by exhortations about national responsibilities to populate the 'Empty North'. National governments have been conscious of their putative responsibilities to the extent of having, at times, a Minister for Northern Development. Rogers (1976), cited in Courtenay (1982, 280), has recognised three recurring justifications advanced in support of northern development, which he designates as the Maginot syndrome ('populate or perish'), the Everest syndrome (ultimate rewards only through initial hardships) and the Malthus syndrome (responsibilities to produce food for a hungry world). These syndromes are all strongly tied to productivist goals.

From the mid-twentieth century there has been a procession of publicly funded or assisted agricultural development schemes with Humpty Doo, Tipperary, Camballin and Douglas-Daly among the failures and the Ord River irrigation project long in gestation (Courtenay, 1982). There has been parallel public support for the pastoral industry through intensive, long-term research into herd nutrition, focusing on introduced grasses and legumes, into herd efficiency using Brahman and other resilient, tick-resistant breeds and into improved infrastructure, as in the beef roads and telecommunications projects.

Projects and programmes have been accompanied by unrealistic expectations on outcomes, with hubris infecting even experienced scientists. The leaders of the CSIRO pastoral research programme affirmed that an '... additional 260 million acres of improved pasture will ultimately be established, we shall be able to carry an extra 52 million cattle' leading to a sevenfold increase in cattle numbers and a tenfold increase in production. They reminded doubters that they should '... recall that in summer rainfall tropical regions, maximum soil moisture coincides with maximum solar energy to give very high pasture growth potential.' They concluded with the exhortation that '.. we owe it to both the Australian and world communities to develop these resources to their utmost.' (Davies and Eyles, 1965, 88-91)

Optimistic predictions by agronomists and other experimental scientists have always been tempered by the views of experienced field workers and producers, aware of the climate disabilities, the infertile soils and the heavy cost burdens tied to remoteness and lack of infrastructure (Beattie, 1956; Perry, 1960; 't Mannetjee et al., 1976; Tothill and Mott, 1985). Cost burdens and environmental disabilities were explored by the agricultural economist, Bruce Davidson, in his controversial book The Northern Myth (1965). Davidson's polemical contribution, backed by a wealth of cost data abstracted from official sources, sparked an ongoing nationwide debate about northern futures. With the wisdom of hindsight, H. C. Coombes, Chair of the former 1946-48 North Australia Development Committee provided a thoughtful critique of the preconceptions and aspirations underpinning proposals for development. 'There was nothing organic in the growth we planned for; it was fundamentally to be based on extractive and exploitative techniques.' (Coombes, 1977, 8)

\section{The other 'frontier': Indigenous co-existence}

Entirely forgotten, in the enduring imagery of the 'development frontier', was the survival of Aboriginal traditional connection to their 'country', often co-existing with non-Indigenous pastoral occupation. Indeed, though highly exploitative of Aboriginal labour in livestock and domestic work, pioneer pastoral occupance often relied upon a mutually beneficial complementary relationship with co-existing traditional (if radically altered) Indigenous occupance. Without underpaid Aboriginal labour, required mainly for the dry-season mustering, branding, droving and domestic activities, pioneer pastoralism could hardly have survived in the remote tropical savannas. During the wet season, when pastoral activities were in abeyance, it suited both parties for the Aboriginal peoples to reconnect with their traditional country and livelihoods by going 'walkabout' (McGrath, 1987; Head, 1994; Baker, 1999). Based on her fieldwork in the tropical savannas, Head $(1994,167)$ demonstrates that 'the co-existence of hunting and gathering with pastoralism is not just a question of multiple use, but one of two types of body politic, or two 
different ecologies'. This right to engage in traditional activities on 'unimproved and unenclosed' land was entrenched in the 1850 Order in Council by which the Colonial Office in London interpreted the provisions in the Imperial Parliament's Australian Waste Land Act 1846. This right was incorporated and maintained in the pastoral leasehold legislation in Western Australia, South Australia and the Northern Territory. However, as pointed out by Head (1994, 167) 'Aboriginal relations to (pastoral) land had been rendered virtually invisible.' In the late 1960s and early 1970 s strong traditional connections to 'country' were being further undermined, most notably following the widespread dismissal of the Aboriginal pastoral workforce and the displacement of many Indigenous peoples from their traditional land, triggered by the introduction of equal wages and a severe depression in the cattle industry. A distinctive mixed-mode of human occupance was disintegrating, seemingly to be replaced by monofunctional, low-input productivist pastoral occupance.

\section{Changing resource values and policy directions}

The persistent record of failure in agricultural development and pastoral intensification accompanied by Indigenous dispossession may have had little impact on policy directions were it not that Australia, along with other affluent western societies, was experiencing a radical re-ordering of purposes underlying human use of rural space, "creating new rural geographies of value' (Marsden, 1999, 507). This wider societal shift, variously described as the shift to postproductivism or to multifunctionality, coincided with the belated recognition of the intractability of the obstacles to agricultural development and the constraints on intensification of pastoralism in Australia's rangelands. The pace of change is in part propelled by past failures. Lack of success in pursuit of productivist goals enhances capability in satisfying 'post-productivist' values. These include national aspirations in the belated recognition of Indigenous land rights, in preserving unique biota and valued natural landscapes, in fostering sustainable land use and promoting distinctive styles of tourism and recreation. Already identified by Young (1981), quoted above, these redirections have been widely acknowledged as evident in background policy documents such as Managing Australia's Rangelands, National Principles and Guidelines for Rangeland Management (ANZECC and RMCANZ, 1999). Also see Morton (1993), Heathcote (1994), Freudenberger and Freudenberger (1994), Holmes (2002) and Gill (2005), as well as Special Issues of The Rangeland Journal, Vol. 16, 1 (1994) 'Contemporary explorations: values, goals, needs and expectations of rangeland users' and Vol. 25, 2 (2003) 'Drivers of change in the rangelands'.

In Holmes (1997, 3), it was noted that the term 'pastoral zone' had been displaced by the nonproductivist descriptor 'rangelands'. Goals, strategies and mechanisms prevalent in the prodevelopment, 'productivist' era were identified and contrasted with those emerging in the 'postproductivist' era. The list included: economic directions; socioeconomic goals; marketable and non-marketable outputs; income sources for landholders; development 'frontiers'; private and public investment; regional transfer payments; research priorities; political power; and local participation.

Within the rangelands, the most substantial transition has been in the tropical savanna zone, given its historical mismatch between expectations and outcomes, reinforced by the emerging realisation of its significant consumption, protection and traditional Indigenous values in semi-pristine ecosystems. These values have been discussed for both broadscale tropical landscapes (Woinarski et al., 2007) and tropical rivers (Jackson et al., 2008). These concerns are reflected in the Strategy Statement 2003-2007 of the Cooperative Research Centre for Tropical Savannas Management (Tropical Savannas CRC, 2003), in which four Research Themes are identified, namely: Landscape Ecology and Health; Industry and Community Natural Resource Management; Regional Planning and Management; and Human Capability Development. Further insights into the research and extension activities of this CRC can be gained from its quarterly publication titled Savanna Links or its website at savanna.cdu.edu.au.

However, in this transition, realities may lag behind rhetoric. In a critique of Stages One and Two of the Ord River Irrigation Scheme, Head has argued that 'despite a context in which a consideration of both Aboriginal and environmental issues is now integrated into the development process, three colonial themes persist in the rhetoric of Stage Two. These are the empty landscape, the invisible Aborigine, and the idealisation of agricultural land use.' (Head, 1999, 141) While accepting the cogency of Head's analysis, the critical change since Ord Stage One is that these colonial visions no longer remain 
uncontested. Alternative non-productivist, 'postcolonial' values are now in play, with clear indicators of regionally differentiated outcomes according to the relative strength of contesting values and interests.

\section{Indicators of a multifunctional transition}

Given the complexities of rural change, there is potentially a large array of indicators recording the dimensions and directions of the multifunctional transition. These indicators include land tenure, ownership, use, management and markets; property rights and duties; investment sources and priorities; employment structure; income sources; avenues for capital accumulation; and also involve policy agendas, actors, contests and decision processes. In Australia's northern savanna zone, however, with one notable exception, very few of these indicators are readily measured at an appropriate regional scale. The exception is the objective record of changes in land tenure, land use and land ownership, together with legislated changes in the property rights and duties attached to land titles notably for pastoral and Aboriginal tenures. This tenure record is a critical indicator, not only because of its clarity and verifiability but also because, more so than in well-settled zones, shifts in land title, land ownership and property rights are the most influential mechanisms for the achievement of a transition towards multifunctionality. An overview of these changes for Aus- tralia's rangelands has already been presented in Holmes (2002, 367-372).

\section{Changes in land tenure and ownership: 1976-2006}

For the tropical savannas, changes in land tenure and ownership from 1976 to 2006 are presented in Figures 1 to 4 and Tables 2 and 3. 1976 is the pivotal year marking a decisive shift in policies, legislation and outcomes. In that year the federal parliament enacted the Aboriginal Land Rights (Northern Territory) Act 1976, creating a radically different land title, namely non-transferable freehold, held by the traditional owners with Land Councils having a statutory role as agents for traditional owners. Immediately following this legislation, in the Northern Territory there was a substantial transfer of Aboriginal reserves, vacant crown land and Aboriginal-held pastoral leases to non-transferable freehold title. The federal legislation, applicable only to the Northern Territory, has triggered land tenure and management transfers affecting Aboriginal reserves and other tenures in Queensland and Western Australia. Also shown in Figures 1 and 2 are the pastoral leases purchased on behalf of Aboriginal traditional owners, undertaken mainly by the federally-funded Indigenous Land Corporation. Only three leases had been transferred before 1976. See Table 1 and Figure 1 for details.

1976 is also a useful indicator year in the history of land transfers to the conservation

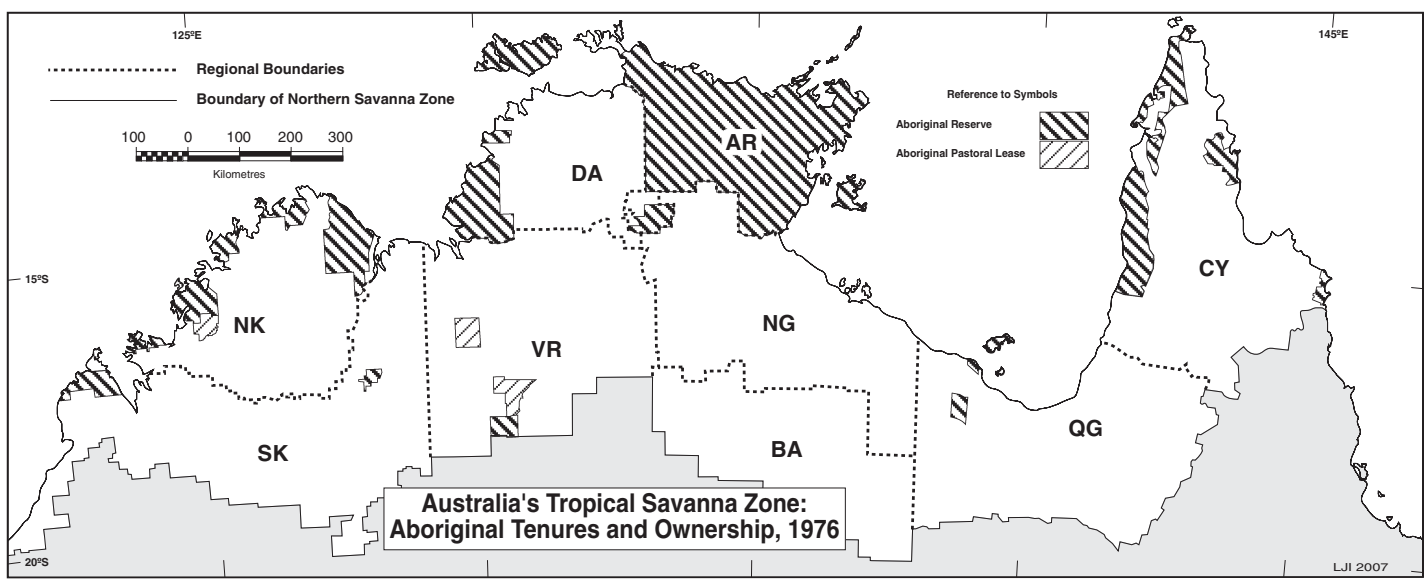

Figure 1 Australia's tropical savanna zone: Aboriginal tenures, 1976.

Sources: AUSLIG (Australian Surveying and Land Information Group) 1993 Map of Australian Land Tenure, Canberra, Government Printer, with amendments and corrected data for benchmark year based on maps, files and correspondence with land tenure administrators in Queensland, Northern Territory and Western Australia. 


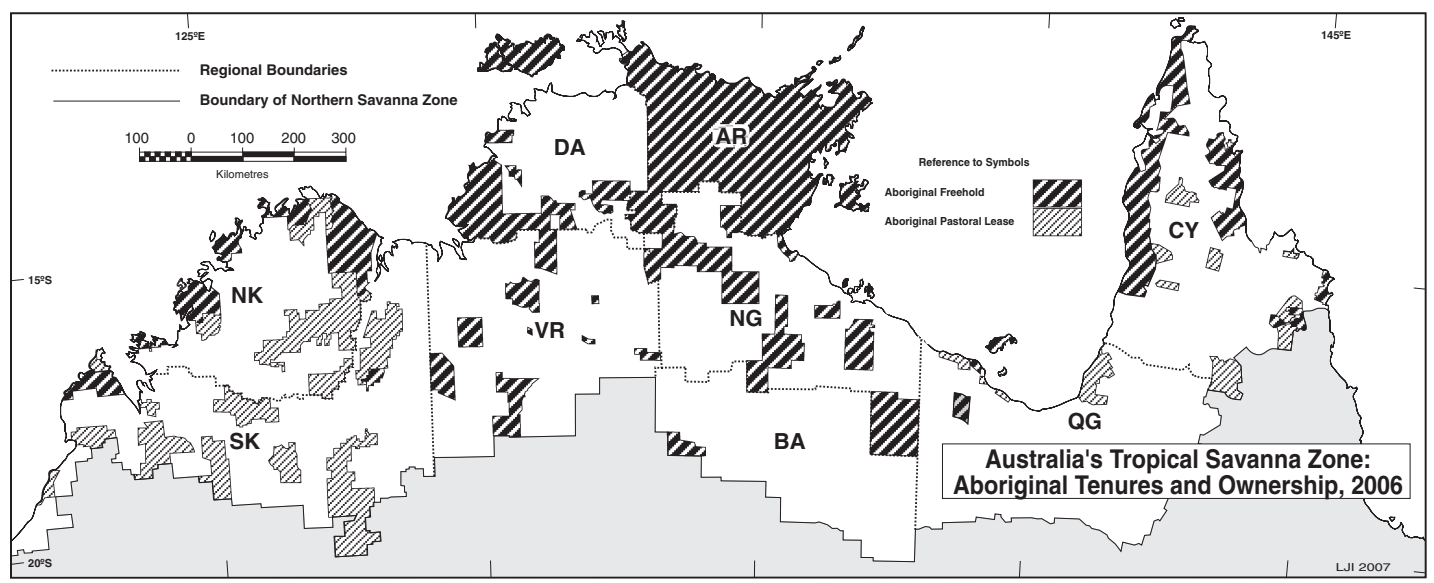

Figure 2 Australia's tropical savanna zone: Aboriginal tenures, 2006.

Sources: As for Figure 1.

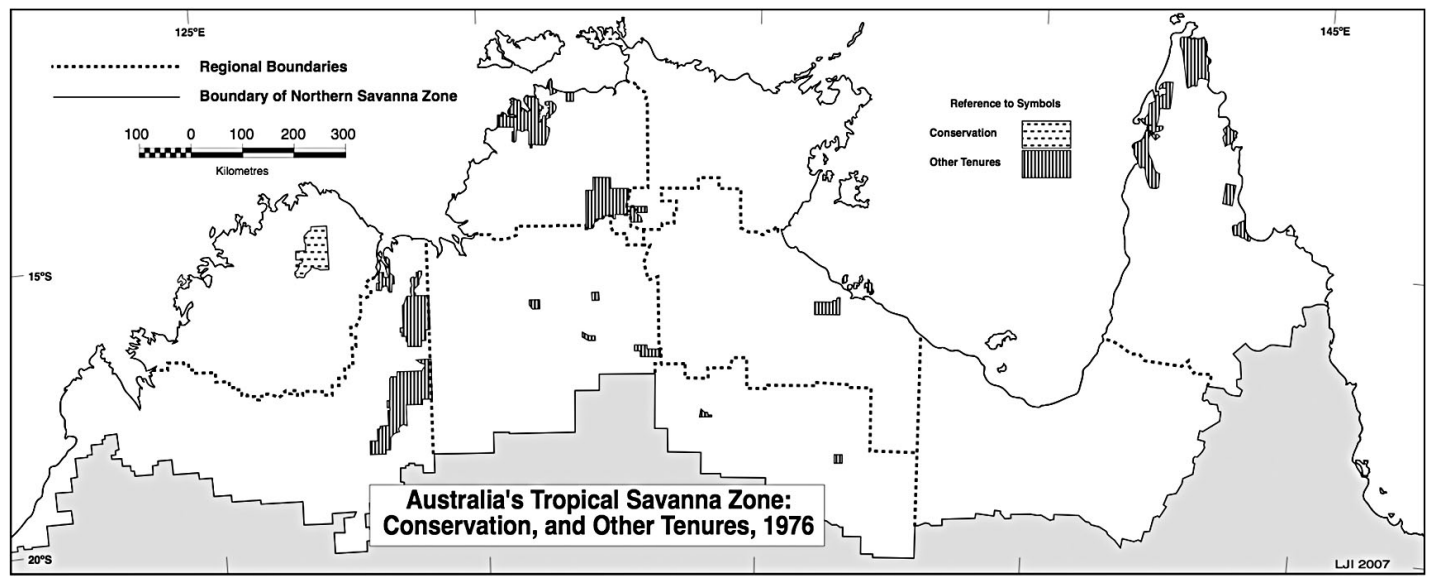

Figure 3 Australia's tropical savanna zone: Conservation and other tenures, 1976.

Sources: As for Figure 1.

estate. Table 1 shows that, in each of the three jurisdictions, only one National Park or Conservation Reserve had been declared prior to 1976, in each case embracing only a small area. Immediately after 1976, there was a succession of transfers. In 1977, six National Parks embracing 10,223 square kilometres, were declared in Cape York Peninsula, with at least some being intended to pre-empt their purchase on behalf of Aboriginal traditional owners. Additional National Parks were declared within the following few years in all three jurisdictions.

As shown in Figures 1 and 2 and in Tables 2 and 3 , the biggest shift has been in the expansion of Aboriginal land, from 188,116 square kilometres in 1976 to 341,119 in 2006 (from 15.2 percent to 27.5 percent of the total area). From the perspective of Aboriginal ownership and selfmanagement, the shift has been much more substantial, with the transfer of state-administered Aboriginal reserves either to de jure Aboriginal ownership by change in land title (as in the Northern Territory) or to a mix of de jure and de facto 'ownership' by legislated transfer of powers in land management and use (as in Queensland and Western Australia). In 1976, self-managed Aboriginal land was negligible, comprising only three recently purchased pastoral leases $(0.6$ percent of the land area), with self-management in its formative stage. In the tropical savannas, direct responsibilities of Indigenous people in land management have expanded from near-zero 


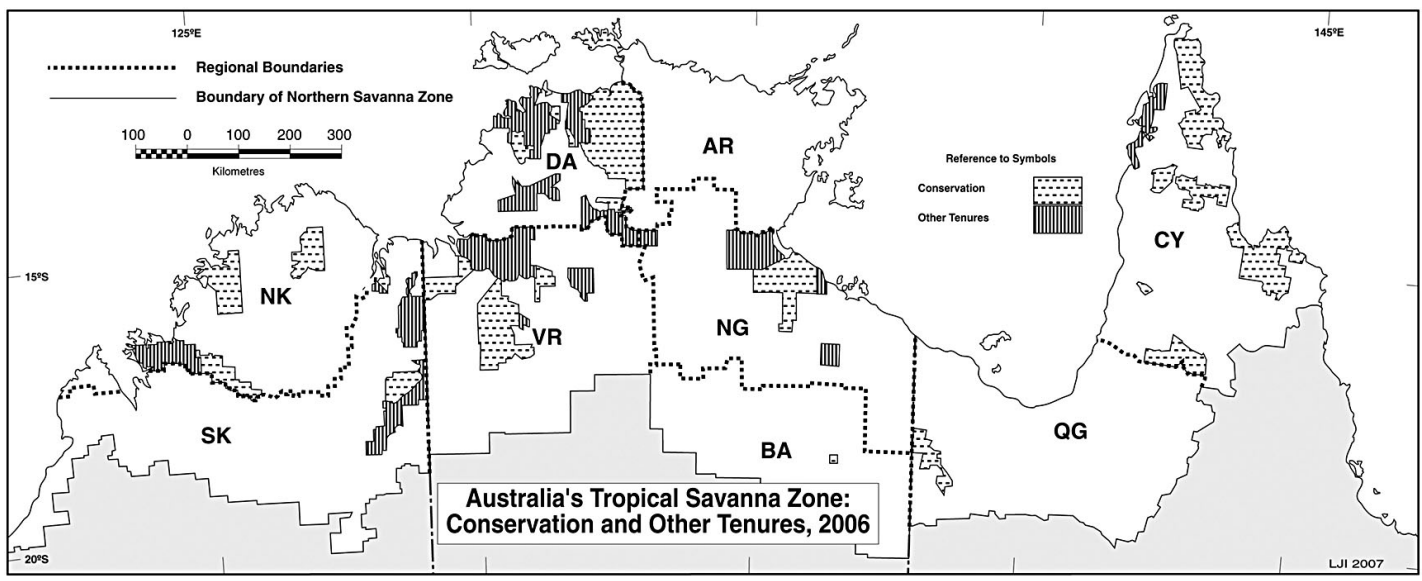

Figure 4 Australia's tropical savanna zone: Conservation and other tenures, 2006.

Sources: As for Figure 1.

Table 1 Australia's tropical savannas: the first conservation areas and Indigenous-owned pastoral leases.

\begin{tabular}{|llcl|}
\hline \multicolumn{2}{c|}{ Conservation Areas } & \\
\hline State/Territory & Area Name & Land Area (km) & Date Gazetted \\
\hline Western Australia & Drysdale River N.P. & 4483 & 1974 \\
Northern Territory & Cobourg Peninsula Reserve & 2207 & 1924 \\
Queensland & Cape Melville N.P. & 360 & 1973 \\
\hline & \multicolumn{1}{c}{ Indigenous-Owned Pastoral Leases } & Date Purchased \\
\hline State/Territory & Area Name & Land Area (km) & 1972 \\
\hline Western Australia & Pantijan & 1744 & 1973 \\
Northern Territory & Amanbidgi (Kildurk) & 2830 & 1982 \\
\hline
\end{tabular}

Notes: The status and extent of Cobourg Peninsula Flora and Fauna Reserve (now National Park) have varied over time. The initial areal extent was approximately the same as shown in the table, which is the current area.

The first intended Aboriginal-owned pastoral lease in Queensland was Archer Bend in 1977. However, this purchase was prevented by the Queensland government by the manoeuvre of gazetting the lease as a National Park.

to over 27 percent of the land area. To this area can be added the 8.1 percent of total area currently held in National Parks, almost all now held as long-term or perpetual leases from Aboriginal owners or with co-management agreements. In addition Aboriginal participation in resourcerelated decisions has recently extended over major tracts of land held in other tenures over which co-existing common-law native title has been recognised or has yet to be determined. In July 2008, the Australian High Court recognised a right to Indigenous exclusive possession of intertidal lands held by the Yolgnu peoples, with a probability that this will be extended to include Indigenous possession of approximately 80 percent of the coastline and tidal waters of the Northern Territory.

\section{Creation of Indigenous land titles}

Of critical importance in this shift has been the creation of two innovative tenures which differ radically from any previous land titles within Australian jurisdictions. These are: commonproperty, non-transferable Aboriginal freehold title held by 'traditional owners', derived from legislative action; and common-law Aboriginal 
Table 2 Australia's tropical savannas: areas in major tenure and ownership categories, 1976-2006.

\begin{tabular}{|c|c|c|c|c|}
\hline \multirow[t]{2}{*}{ Tenure/Ownership } & \multicolumn{3}{|c|}{ Area (square kilometres) } & \multirow[t]{2}{*}{ Total } \\
\hline & Queensland & Northern Territory & Western Australia & \\
\hline Private pastoral lease 1976 & 240,719 & 462,935 & 234,731 & 938,385 \\
\hline Private pastoral lease 2006 & 197,843 & 342,725 & 169,775 & 710,343 \\
\hline Aboriginal pastoral lease 1976 & - & 6,186 & 1,744 & 7,930 \\
\hline Aboriginal pastoral lease 2006 & 16,299 & - & 64,324 & 80,623 \\
\hline Aboriginal freehold 1976 & - & - & - & - \\
\hline Aboriginal freehold 2006 & 29,722 & 204,796 & 25,978 & 260,496 \\
\hline Aboriginal reserve 1976 & 27,772 & 126,436 & 25,978 & 180,186 \\
\hline Aboriginal reserve 2006 & - & - & - & - \\
\hline Conservation lands 1976 & 360 & 2,207 & 4,483 & 7,050 \\
\hline Conservation lands 2006 & 32,657 & 50,803 & 17,443 & 100,903 \\
\hline Vacant crown land 1976 & - & 30,222 & 36,608 & 66,830 \\
\hline Vacant crown land 2006 & - & - & 20,364 & 20,364 \\
\hline Other tenures 1976 & 11,842 & 14,405 & 13,832 & 40,079 \\
\hline Other tenures 2006 & 4,172 & 44,067 & 19,492 & 67,731 \\
\hline Total area 1976 and 2006 & 280,683 & 642,391 & 317,376 & $1,240,460$ \\
\hline
\end{tabular}

Sources: Land tenure maps and files provided by administrations in Queensland, Northern Territory and Western Australia. Notes: In Queensland and Western Australia, some lands classed in 2006 as Aboriginal freehold are held in other tenures which provide comparable property rights.

Other tenures include private freehold, mining tenures, defence lands and other lands held by state and territory governments.

Table 3 Australia's tropical savannas: Percent of areas in main tenure and ownership categories, 1976 and 2006.

\begin{tabular}{|c|c|c|c|c|}
\hline \multirow[t]{2}{*}{ Tenure/Ownership } & \multicolumn{3}{|c|}{ Percent of Area } & \multirow[t]{2}{*}{ Total } \\
\hline & Queensland & Northern Territory & Western Australia & \\
\hline Private pastoral lease 1976 & 85.8 & 72.1 & 74.0 & 75.7 \\
\hline Private pastoral lease 2006 & 70.5 & 53.4 & 53.5 & 57.3 \\
\hline Aboriginal pastoral lease 1976 & - & 1.0 & 0.5 & 0.6 \\
\hline Aboriginal pastoral lease 2006 & 5.8 & - & 20.3 & 6.5 \\
\hline Aboriginal freehold 1976 & - & - & - & - \\
\hline Aboriginal freehold 2006 & 10.6 & 31.9 & 8.2 & 21.0 \\
\hline Aboriginal reserve 1976 & 9.9 & 19.7 & 8.2 & 14.5 \\
\hline Aboriginal reserve 2006 & - & - & - & - \\
\hline Conservation lands 1976 & 0.1 & 0.3 & 1.4 & 0.6 \\
\hline Conservation lands 2006 & 11.6 & 7.9 & 5.5 & 8.1 \\
\hline Vacant crown land 1976 & - & 4.7 & 11.5 & 5.4 \\
\hline Vacant crown land 2006 & - & - & 6.4 & 1.6 \\
\hline Other tenures 1976 & 4.2 & 2.2 & 4.4 & 3.2 \\
\hline Other tenures 2006 & 1.5 & 6.9 & 6.1 & 5.5 \\
\hline Total 1976 and 2006 & 100 & 100 & 100 & 100 \\
\hline
\end{tabular}

Sources and Notes: See Table 2.

native title, also held by 'traditional owners', the outcome of judicial discovery in the 1992 Mabo and 1996 Wik decisions of the High Court, which then required codification through legislation (Hiley, 1997).

Land transfers to Aboriginal ownership have been accompanied by radical changes in Indig- enous control of their returned lands. Consistent with the Aboriginal Land Rights (Northern Territory) Act 1976, Aboriginal-held lands in the Territory, whether previously reserve, vacant crown land or a purchased pastoral lease, have subsequently been converted to non-transferable freehold tenure, held by the traditional owners 
as de facto common property. In Queensland, former reserves have been transferred into land grants equivalent to freehold. In Western Australia, the ultimate responsibility for the administration of reserves has been transferred from public servants to an Aboriginal representative body. However, in Queensland and Western Australia, Aboriginal-held pastoral leases are usually subject to the same provisions on property rights and duties as are those of other lessees.

Transitions in land tenure have acted as instruments for the empowerment of Indigenous leadership, now endowed with a critical role in resource decisions (Keon-Cohen, 2001). Altman and Dillon $(1988,126)$ argue that ... 'It is incontrovertible that the (1976) Act has significantly altered the structural position of Aboriginal people in the Northern Territory political economy ... both Territory and federal governments continue to emphasise that the land councils' statutory roles are to merely act as agents for traditional owners of land. However, land councils are operating increasingly as guardians of Aboriginal interests and representatives of Aboriginal people's views and aspirations. Whether exercised through land councils or directly by the traditional owners, land tenure and associated resource rights are the catalysts for Aboriginal engagement in shaping resource outcomes and the division of benefits.'

Land tenure issues in North Australia have been the catalysts for all significant national actions in recognising Indigenous land rights. These events include the bark petition of the Yolngu people in 1963, the Wave Hill walk-off by the Gurindji people in 1966 and the subsequent lease transfer in 1974, the passing of the Aboriginal Land Rights (Northern Territory) Act in 1976, the Mabo (1992) and Wik (1996) High Court determinations that recognised commonlaw native title and found that it may co-exist alongside pastoral lease tenures, and, the 2008 High Court determination in the Blue Mud Bay case recognising native title over certain intertidal and estuarine zones.

These actions have provided a substantial legal basis for Indigenous self-management over extensive land tracts as partly shown in Figure 2. In Holmes (2006), I identified an Indigenous mode of human occupance within Australia, positioned with a Conservation mode with both focused on protection values. This interpretation needs reappraisal. While all Indigenous landholders place a premium on protecting traditional sites and elements of the cultural landscape, they may also pursue commodified production and consumption outputs, tied to the marketable values of their lands and customs. Noting that 'the economic is always socially embedded', Gill $(2005,703)$ emphasises the reality of hybrid Aboriginal economies and the mutual constitution of cultural, social and economic realms.' The Indigenous mode of occupance is characterised by a distinctive set of ethno-cultural values and land tenure/ownership attributes rather than by the relative weights awarded to production, consumption or protection values.

\section{Indigenous occupance on former pastoral leases}

In 1976, across the tropical savannas, only three pastoral leases embracing 7930 square kilometres were Indigenous-owned. By 2006, 69 pastoral leases had been transferred to Indigenous ownership, embracing 82,573 square kilometres. Of these leases, 25 in the Northern Territory had been converted to non-transferable Aboriginal freehold title. Insights into the relativities between commercial pastoralism, non-pastoral enterprises and traditional values can be gleaned from the selected case studies included in the annual reports of the Indigenous Land Corporation. Further insights can be gained in Young et al. (1991), Young and Ross (1994), Central Land Council (1996), Baker et al. (2000), Lane (2002; 2005), Davis (2004) and Gill (2005). There is a spectrum in Indigenous land occupance, ranging from fully commercial, unsubsidised, centrally managed businesses through to non-commercial, decentralised operations, with cattle treated as a subsistence resource. Most lease purchases have been of non-viable stations, located on marginal pastoral lands in Cape York Peninsula, the Northern Territory Gulf Country and the Kimberley District. As reported in my 1985 survey into the viability of all Northern Territory Gulf stations, these non-viable stations made a negligible contribution to beef production and were a burden on herd management and disease control programmes (Holmes, 1990). Given their inability to provide a livelihood for a non-Indigenous lessee, it is unrealistic to expect these leases to generate pastoral income to support a more numerous Indigenous community. On these leases, Aboriginal owners, for good reason, rarely pursue commercial pastoral enterprises, retaining only a small 'killer' herd for domestic consumption, and possibly seeking a modest income from tourism and recreational fishing markets and for a flourishing art 'indus- 
try' (Young and Ross, 1994). However, the main income source remains welfare payments, which also have been the mainstay of the local economy (Crough and Christophersen, 1993).

A much smaller number of lease purchases have occurred on core pastoral lands. There is a near-inverse relationship between pastoral productivity (and related intensity of pastoral management) and survival of traditional Indigenous connection to country (Holmes, 2002, 370-371). The cost of purchase would be disproportionate to the anticipated benefit through the return and restoration of depleted traditional Indigenous values. On the prime pastoral lands of the Barkly Tableland only one lease, the least productive within the region, has been purchased, whereas in the South/East Kimberley, 22 have been acquired. Almost all of these leases on core pastoral lands are still engaged in commercial pastoralism, with variable management styles and financial outcomes. Noting the high social status of pastoralism among northern Indigenous peoples, Davis (2004) provides insights into the ways in which ownership of land and livestock may lead to considerable change in Aboriginal social order, evidenced in tensions and conflicts between a traditional view of cattle as a foraging resource tied to decentralised traditional use and a more commercial strategy with centralised management of herd and infrastructure. Davis $(2004,36)$ considers that 'a stratum of relatively wealthy land-based Aboriginal families will emerge, inaugurating a unique form of social differentiation.'

\section{Expansion of the conservation estate}

Quite apart from Aboriginal land rights, there are other emerging national 'post-productivist' goals, where the tropical savannas assume significance greater than awarded in the 'productivist' era. Of these, the most notable is the conservation of biodiversity and of near-pristine landscapes. Bridgewater and Walton (1996) have emphasised that the tropical savannas are a 'complex, heterogeneous landscape', which has been subject to much less modification than most other bioclimatic zones, with significant benefits in adopting a holistic, landscape-oriented approach, including broadscale nature reserves and compatible management of land outside these reserves. This case has recently been persuasively restated by Woinarski et al. (2007). As shown in Figures 3 and 4 and Table 2, the area in the 2006 public conservation estate is over thirteen times greater than in 1976, expanding from
0.6 to 8.1 percent of land area. In addition, a few pastoral leases have been purchased by private, non-profit conservation organisations, with more effective management towards preservation goals than those prevailing on the public conservation lands.

As elsewhere in Australia, protection values are gaining recognition through federal and state legislation, notably in the Landcare programme, the Natural Heritage Trust and strict controls on the clearing of native vegetation. The tropical savannas have also received zonally-targetted protection legislation in recognition of their distinctive broadscale conservation values. In particular, Cape York Peninsula has achieved icon status as a near-pristine 'wilderness' of global significance. As described later, concerted metropolitan-based national conservation campaigns have prompted vigorous responses from local Indigenous and non-Indigenous groups, requiring a succession of federal and state actions designed to provide an institutional framework including a reallocation of land tenures and property rights to accommodate future complex multifunctional occupance.

\section{Emergence of tourism and recreational activities}

Although not recognised on maps of land tenure, a third 'post-productivist' activity of growing significance in the tropics is tourism. The tropical savannas are highly attractive for mobile, safaristyle tourism and recreational fishing, both characterised by extended stays at low daily expenditures. Visitor 'self-sufficiency' is derived from prior substantial expenditures in source locales, generating only limited local service demand in the tropical savannas. Modest regional multipliers are gradually being augmented as local people, Indigenous and non-Indigenous, acquire skills and facilities to capture tourist dollars. Examples include coordinating organisations such as Savannah Guides, tourism facilities on many pastoral stations and remote modest resort facilities on Indigenous lands offering a distinctive tourist experience. Local economic and social impacts of tourism have been scrutinised in the publications of the Tropical Savannas Cooperative Research Centre (Yu and Yu, 2003; Greiner and Larson, 2004; Greiner et al., 2004; 2005).

\section{Retreat of pastoralism}

Traditional pastoral hegemony over the savannas land resource is now contested, as evidenced in 
land transfers and also in the legislated rights and duties of pastoral lessees. As shown in Table 3, the percentage of land within the zone held by private non-Indigenous pastoral lessees has declined from 75.6 to 57.3 , representing a decline of 24.3 percent of the 1976 privately held pastoral area. There has been a major retreat across all regions save only the Barkly and Queensland Gulf regions, the two regions with the highest resource potential and locational advantage.

Pastoralism's long-standing primacy has been questioned in legislated changes in the rights and duties attached to pastoral leases. Significant changes are fully described in Dawson (2002) and summarised in Holmes (2002, 367-9). As elsewhere in Australia, legislation and administration relating to lease tenures, until recently, had a strongly 'productivist' orientation, directed towards pastoral development. Duties were imposed on lessees to 'stock the land, and keep the land stocked, in accordance with the provisions of the lease', to 'comply with the laws in force relating to the destruction of vermin and noxious weeds' and to 'comply with the requirements of the lease as to development work as varied from time to time by the Minister under section 37A of the Ordinance' (Northern Territory Crown Lands Act, 1981). Comparable stocking, development and maintenance requirements were incorporated in Queensland and Western Australian legislation. While the superseded legislation did not provide a statement of objectives, its provisions were almost entirely concerned to promote development or assert retained rights to the Crown, save only for recognising the entrenched access rights of the Aborigines as well as limited public access rights, together with restrictions on land aggregation above 5000 square miles.

Typical putative 'post productivist' policy changes can be seen in the stated objectives of the Northern Territory's Pastoral Land Act, 1992, with these objectives being: to facilitate sustainable use; to ensure economic viability; to monitor the condition of the pastoral land; to prevent or minimise degradation or damage to indigenous plant and animal life; to rehabilitate land; to provide reasonable public access; to recognise the rights of Aborigines to follow traditional pursuits; and to provide for the establishment of Aboriginal community living areas on pastoral land. However, loosely-worded legislation may serve to minimise policy change. As pointed out by the Industry Commission (1998,
171) 'a lack of enforceability will discredit a regulatory regime'. Dawson $(2002,179)$ concludes that 'As currently framed, the duties of care in the Pastoral Land Act, lack credibility and may well be ignored by those to whom they may apply. They may, in practice, create an obstacle to biodiversity conservation by lulling the public into a false sense of security.'

In any case, the 1993 Northern Territory Act has provided tenure security by enabling term leases to be converted to perpetual leases. Almost all leases have subsequently been converted. Dawson $(2002,173)$ considers this provision as 'arguably the most significant change introduced in the 1992 Act ... (with) no possibility of forfeiture of a perpetual pastoral lease for breach of the lease conditions.' This legislation reflects the continuing strong pastoral influence in the Northern Territory, notwithstanding its modest and declining economic contribution and also in spite of strong counter-influences. These interestconstituencies were evident only five years earlier when a proposal to allow lease conversion to freehold tenure was hastily abandoned after it met unexpectedly strong opposition from mining, conservation, Aboriginal, recreational, tourism and other urban interest groups, with recreational fishermen exercising a decisive role.

\section{Multiple-value, multiple-use contests: Cape York Peninsula}

Previously protected by remoteness and by ample space to accommodate modest demands from diverse interests, the tropical savannas are increasingly being drawn into complex contests between multiple interests and ideologies. These contests are usually focused on circumscribed 'resource-rich' patches leading to complex multifunctional occupance, with these patches embedded within extensive tracts of low potential. These localised 'rich patches' include riverine, riparian, estuarine, wetland and coastal zones which are also highly valued by Indigenous, pastoral, tourism and conservation interests. Other locales include gorges, cliffs, waterfalls, caves and 'lost city' formations, often with a rich Indigenous heritage and increasingly attractive to tourism. In practice, emerging complex multifunctional occupance is localised within these highly contested patches embedded within extensive tracts of low potential.

While contested futures are emerging for other savanna regions, Cape York Peninsula in particular has been the focus of intense, continuing political engagement for almost two decades. 
Major participants include Aboriginal traditional and contemporary, as well as local and non-local, interests (often divided along clan groupings), reconciliation advocates, conservationists, tourism entrepreneurs, pastoralists, speculators, developers, lawyers, courts and tribunals, statutory organisations and agencies of federal, state and local governments. These interest-groups are engaged in a complex maze of decision processes, compelling a succession of controversial interventions by state and federal governments. The debate on regional futures was initially driven by influential national and state conservation and Indigenous advocacy organisations. Contests have been intensified by the responses of local pastoral and Indigenous constituencies and by tourism operators and recreational interests.

As in comparable frontier zones, such as northern Canada (Fenge and Rees, 1987), these contests compel a governmental response, requiring some attempt, however imperfect, towards strategic regional planning. In each of the northernmost 'frontier' regions, north Kimberley, Northern Territory Gulf Country and Cape York Peninsula, governments have, at least, recognised this need, though with mixed results (Holmes, 1992; Howitt, 1993). Confronted with these emerging contests, in the early 1990s federal and state governments jointly initiated an ambitious five-year scoping study, titled the Cape York Peninsula Land Use Strategy (CYPLUS). Although stating that 'public participation will be the cornerstone of the entire project', most of the funding was committed to 26 research projects without any public consultation (Baird, 1996). Alarmed by the externally-driven, bureaucratised, technocratic CYPLUS programme, and also by a state government proposal to create a continuous East Coast Conservation Zone, embracing over two million hectares, in the mid1990s an uneasy alliance of local pastoral and Indigenous interests engaged with conservationists in drafting the Cape York Peninsula Heads of Agreement, designed to ensure a continuing local role in the allocation and management of local resources.

As shown in the 2006 map of conservation tenures (Figure 4), the state government has recently purchased all remaining pastoral leases to accomplish its East Coast Conservation Zone. However, to accommodate Indigenous interests the state government has also pursued a 'Tenure Resolution Process' by which most conservation lands will be held as Aboriginal freehold, with a perpetual lease to the state enabling National Park declarations. Indigenous traditional owners will have a major role in management of these conservation lands. Also under negotiation is the allocation of some of the purchased land to Indigenous tenures for purposes other than conservation. When completed, this will involve a re-mapping of some conservation lands, shown in Figure 4, to Indigenous occupance.

Also recently, local Indigenous and nonIndigenous concerns have been reignited by two major state legislative actions, firstly the Native Vegetation Management Act 1999 controlling the clearing of native vegetation and the Wild Rivers Act 2005 designed to constrain development in the catchments of 'wild rivers'. It is not surprising that almost all the wild rivers proposed for gazettal are located in the Peninsula, with 13 proposed in this region. In recognition of these concerns, the Cape York Peninsula Heritage Bill, introduced into the Queensland Parliament in June 2007, provides incentives for biodiversity preservation, while securing the interests of Indigenous peoples, pastoralists, miners, recreationists and tourism operators.

In Cape York Peninsula the Indigenous case has been successfully articulated by a number of active, effective leadership groups, capable of matching the campaigns of national conservation organisations such as the Australian Conservation Foundation and the Wilderness Society. Of the Indigenous organisations, the most influential has been that led by Noel Pearson, whose ideas have played a major role in the recent reorientation of national and state policies away from welfarism and towards social and economic integration (not necessarily assimilation). Pearson's Cape York Institute for Policy and Leadership '... champions reform in Indigenous economic and social policies to enable the people of Cape York to have the capabilities to choose a life that they have reason to value.' In this highly contested arena, the emerging potential divide is between traditionalist and modernist visions of Indigenous futures, with this divide influencing the agendas and strategies of non-Indigenous power groups.

\section{Cross-currents and counter-currents: potential re-directions in functional trajectories}

Since European settlement, human occupance in this marginal zone has historically been sensitive to external drivers. Given current global trends, external drivers may become even more influen- 
tial, as briefly explored for North Australia in Garnett et al. (2008, v). Recognising that there are 'implacable uncertainties', the authors identify ten influential drivers and 'consider how these drivers may interact to determine more or less plausible alternative futures (scenarios).' Major drivers considered are: demography; social function; land tenure and associated property rights; Commonwealth policy; globalised trade and the international economy; resource use; oil futures; global climate change; invasive organisms; and innovation and technology. Alternative future scenarios scrutinised are titled: chronic underdevelopment; degeneration; northern ricebowl; industrial powerhouse; environment first; Indigenous community Utopia; and creative urban engagement. This diverse set of scenarios serves to emphasise the socioeconomic and ecological fragility of this frontier zone and its sensitivity to unpredictable, mainly external, influences.

These uncertainties persist even when the objective is narrowed to a consideration of the relative future roles of production, consumption and protection values in shaping rural occupance.

Trends over recent decades have pointed to a continuous, near-universal, if variable, ongoing transition towards enhanced multifunctionality in Australia's tropical savannas zone. While globalscale driving forces and national socioeconomic directions are maintained along their current trajectories, this transition can be expected to continue, though possibly with loss of momentum. However, given the increasing volatility in global biophysical and socioeconomic systems, any assumptions about future driving forces and national directions need critical scrutiny. Possible global and national changes could lead to regional re-directions and even partial reversals in functional trajectories.

In Holmes (2006), I identify three overarching driving forces propelling the transition towards multifunctionality in rural occupance in western societies namely: agricultural overcapacity; the emergence of market-driven amenity values; and growing societal awareness of sustainability and preservation values. Of these, the most potent re-direction is in the supply-demand ratios for agricultural outputs at the global scale and within Australia. While overcapacity appears to be an endemic attribute of technologically driven, capital-intensive farming systems, this may be reversed with potential food and fibre shortages arising from resource depletion, climate change, carbon-emission constraints, energy shortages, growing demand for biofuels or other causes which lie beyond the scope of this discussion. Projected zonally differentiated outcomes from global climate change may contribute to a northwards redistribution of farming systems. Already, in Australia, the former federal Coalition government created a task force to re-examine agricultural potentials and development strategies for the tropical north in response to the evidence of rainfall decline and water shortages across the southern agricultural heartlands. Notwithstanding past failures in the northern savannas, circumstances may now converge to surmount environmental and locational constraints, leading to localised successes in largescale farming projects. There remain strong national impulses which 'naturalise the development process as both inevitable and strategically implemented.' (Head, 1999, 141)

Conversely, higher energy costs may pose serious challenges to those production and consumption sectors reliant on high energy inputs relative to total inputs or to financial returns. This is particularly so for sectors with high transport costs. Among these are the large multilocational, vertically integrated pastoral companies with northern stations specialising in breeding for fattening at distant properties further south and east. One of the largest chains is selling its three Kimberley stations, carrying over 30,000 head and furthest removed from its other properties. The managing director stated that: 'The increasing cost of fuel, with its impact on livestock freight, has forced a review of (our) breeding, growing and finishing strategies.' (Weekend Australian, 2-3 August 2008) The managing director pointed out that these stations were well suited for live seaborne export to Asia, which has become an increasingly important sector offering enhanced productivity and rapid-turnoff as well as lower transport costs.

Remote-area tourism and recreation activities are also very sensitive to transport costs. Recent growth in both free-ranging safari and resortbased tourism as well as private traveling in fourwheel drives, campervans and caravans may be reversed by accelerating energy costs.

New directions in nature conservation are also likely to emerge, with less emphasis on 'locking up' land in conservation reserves. These remain under-resourced, under-managed and prone to invasions of feral plants and animals, such that their conservation values are increasingly being questioned. Woinarski et al. (2007) provide an authoritative and persuasive case that the greatest 
conservation value of northern Australia is its extensiveness, natural integrity and the maintenance of ecological processes over large scales, requiring strategies which recognise the zone's exceptional status as a coherent biological and environmental entity. They advocate that people in the landscape, Indigenous and nonIndigenous, should be rewarded for managing to achieve conservation outcomes. Multifunctional occupance would be achieved through recognition of multi-value synergies across the landscape rather than through the land tenure/ ownership/use demarcations pursued over the last three decades as shown in Figures 1 to 4 . Alternative approaches in land tenure and property rights are explored in Holmes (1996). Functional synergies may extend to the participation of this zone within global-scale carbon sequestration programmes (Williams et al., 2004). As the only tropical savannas bioclimatic zone located in an advanced western country unburdened by population pressures, North Australia is uniquely placed to provide global leadership in maintaining biodiversity and sustainable management practices (Holmes and Mott, 1993).

Indigenous modes must necessarily undergo major changes. Land acquisition for Indigenous ownership may well have run its course, with available funds increasingly directed towards community services, infrastructure and incipient commercial activities on existing lands. Already, both within and outside the tropical savannas, a few Indigenous-owned properties have been sold off. In any case, the extreme dysfunctionality of remote Indigenous settlements is prompting a nationwide questioning of past policies which focussed on restoration of land rights and fostering self-determination, but also contributed to welfare dependency. A major policy reversal towards a closer integration into mainstream society is being forcefully implemented by federal intervention in the Northern Territory, initiated in mid-2007. Supposedly motivated by a desire to eradicate child abuse in remote communities, this intervention has a broad agenda, involving a suite of major policy reversals, including initiation of private landownership via 99-year leases, privatisation of house-ownership, restrictions on welfare payments, removal of the entry permit system to townships, abolition of community employment payments and proposals to establish worktraining programmes. While some governmental aspirations may seem unrealistic, this forceful intervention may lead to the demise of many small, remote communities also with a diminished Indigenous custodial role over traditional lands. More importantly, it represents a decisive policy reversal in the two critical matters of Indigenous resource rights and selfdetermination. Previous assumptions about the further evolution of distinctive modes of Indigenous occupance may need re-examination. If the integrationist policies of the federal government continue to be pursued, Indigenous-owned resource use and occupance modes will become more closely aligned to those prevailing in contemporary mainstream society.

Federal and state government redirections are being prompted by new voices within Indigenous leadership, emphasising closer integration within the mainstream economy and society as the only means by which dysfunctional welfarism can be overcome. The most vocal and influential voice in reshaping policies at both federal and state level has been Noel Pearson and his Cape York Institute for Policy and Leadership with policy statements in such critical areas as welfare reform, health reform, education, economic viability, land, housing and alcohol. Recently, Pearson has forcefully opposed declarations of wild rivers in the peninsula, arguing that these will act as constraints on the sustainable economic growth required to escape the welfare trap. This has led to an increasingly strident national debate between Pearson's vision of an economically viable, multifunctional future on Indigenous country against the vision of a 'deep green wilderness' landscape, equally vigorously pursued by the electorally influential Wilderness Society. This contest about peninsula futures is enmeshed within the parallel contest between modernist versus traditionalist/localist visions of futures for Indigenous remote communities.

The indications are that regional trajectories will continue along paths towards more complex multifunctional occupance modes. Multiple values and uses will be more intermingled and integrated within savanna landscapes rather than by further demarcation of lands dedicated to production, protection or Indigenous purposes.

Among these potential re-directions, the least probable scenario is a return to a predominantly productivist occupance mode across this bioclimatic zone. Reversion could only occur if the global commodity-supply system were near collapse, enforcing absolute priority to production goals. While this extreme scenario is improbable, future directions are not readily ascertainable, given the volatility in global and national dynam- 
ics and the susceptibility of this sparsely settled zone to shifts in occupance trajectories largely driven by external forces. These shifts will be most pronounced on the most marginal lands, where contests and synergies between production, consumption, protection and Indigenous values will continue to generate complexity and uncertainty in the ownership, management and use of Australia's tropical savannas.

\section{ACKNOWLEDGMENTS}

My thanks to land tenure administrators in Queensland, Northern Territory and Western Australia for their assistance in compiling information on land tenures and land ownership for the two benchmark years, 1976 and 2006. Further thanks to referees for thoughtful, constructive comments.

\section{REFERENCES}

Altman, J.C. and Dillon, M.C., 1988: Aboriginal land rights, land councils and the development of the Northern Territory. In Wade-Marshall, D. and Loveday, P. (eds.), Contemporary Issues in Development. North Australia Research Unit, Darwin, 126-154.

Australian and New Zealand Environment and Conservation Council and Resource Management Council of Australia and New Zealand, 1999: Managing Australia's Rangelands, National Principles and Guidelines for Rangeland Management. AGPS, Canberra.

Australian Institute of Political Science, 1954: Northern Australia: Task for a Nation. Angus and Robertson, Sydney.

Baird, M., 1996: A 2020 vision for Cape York Peninsula: a story of 40,000 years plus 200. In Ash, A. (ed.) The Future of Tropical Savannas: an Australian Perspective. CSIRO, Melbourne, 159-164.

Baker, R., 1999: Land is Life: the Story of the Yanyuwa People. Allen and Unwin, Sydney.

Baker, R., Davies, J. and Young, E., 2000: Working on Country: Contemporary Indigenous Management of Australia's Lands and Coastal Regions. Oxford U. P, Melbourne.

Beattie, W.A., 1956: A Survey of the Beef Cattle Industry in Australia. C.S.I.R.O., Melbourne.

Bridgewater, P. and Walton, D. 1996: National Parks and other protected areas. In Ash, A. (ed.) The Future of Tropical Savannas: An Australian Perspective. C.S.I.R.O., Melbourne, 54-61.

Central Land Council, 1996: Still our Country: Aboriginal Perspectives on Rangelands Management. Central Land Council, Alice Springs.

Commonwealth of Australia, 1959: Prospects of Agriculture in the Northern Territory. Department of Territories, Canberra.

Coombes, H.C., 1977: Opening remarks. In Bauer, F.H. (ed.) Cropping in North Australia: Anatomy of Success and Failure. Australian National University, Canberra, 8-9.

Courtenay, P.P., 1982: Northern Australia. Longman Cheshire, Melbourne.

Crough, G. and Christophersen, C., 1993: Aboriginal People in the Economy of the Kimberley Region. North Australia Research Unit, Darwin.

Davidson, B.R., 1965: The Northern Myth. Melbourne University Press, Melbourne.

Davies, J.G. and Eyles, A.G., 1965: Expansion of Australian pastoral production. Journal of the Australian Institute of Agricultural Science 31, 77-93.
Davis, R., 2004: Aboriginal managers as blackfellas or whitefellas? Aspects of Australian Aboriginal cattle ownership in the Kimberley. Anthropological Forum 14, 23-42.

Dawson, F.E., 2002: Love and Loss on the Colonial Frontier: Biodiversity Conservation and the Law in the Pastoral Lands of the Northern Territory. Ph. D. Thesis, Faculty of Law, University of Wollongong.

de Groot, R., 2005: Function analysis and valuation as a tool to assess land use conflicts in planning for sustainable multi-functional landscapes. Landscape and Urban Planning 75, 175-186.

Fenge, T. and Rees, W.E., 1987: Hinterland or Homeland? Land Use Planning in Northern Canada. Canadian Arctic Resources Committee, Ottawa.

Freudenberger, D.O. and Freudenberger, C.D. 1994: Good relationships: ethical and ecological perspectives on rangeland management. The Rangeland Journal 16, 321-332.

Garnett, S., Woinarski, J., Gerritson, R. and Duff, G., 2008: Future Options for North Australia. Charles Darwin University Press, Darwin.

Gill, N., 2005: Life and death in the Australian 'heartlands': pastoralism, ecology and rethinking the Outback. Journal of Rural Studies 21, 39-53.

Greiner, R. and Larson, S., 2004: The Relationship between Landholders and Tour Operators: an Investigation of the Areas adjoining the Gibb River Road in the North Kimberley. Tropical Savannas CRC, Darwin.

Greiner, R., Mayocchi, C., Larson, S., Stoecki, N. and Schweigert, R. 2004: Benefits and Costs of Tourism for Remote Communities: Carpentaria Shire, North-West Queensland. Tropical Savannas CRC, Darwin.

Greiner, R., Larson, S., Herr, A. and Pinger, P. 2005: Independent Travellers in the North Kimberley. Tropical Savannas CRC, Darwin.

Head, L., 1994: Aborigines and pastoralism in northwestern Australia: historical and contemporary perspectives on multiple use of the rangelands. The Rangeland Journal 16, 167-183.

Head, L., 1999: The northern myth revisited? Aborigines, environment and agriculture in the Ord River Irrigation Scheme, Stages One and Two. Australian Geographer 30, 141-158.

Heathcote, R.L., 1994: Manifest destiny, mirage and Mabo: contemporary images of the rangelands. The Rangeland Journal 16, 155-166.

Hiley, G., (ed.), 1997: The Wik Case: Issues and Implications. Butterworths, Sydney.

Holmes, J., 1990: Ricardo revisited: submarginal land and non-viable cattle enterprises in the Northern Territory Gulf District. Journal of Rural Studies 6, 45-65.

Holmes, J., 1992: Strategic Regional Planning on the Northern Frontiers. North Australian Research Unit, Darwin.

Holmes, J., 1996: Changing resource values in Australia's tropical savannas: priorities in institutional reform. In Ash, A. (ed.) The Future of Tropical Savannas: an Australian Perspective. CSIRO, Melbourne, 28-43.

Holmes, J., 1997: Diversity and change in Australian rangeland regions: translating resource values into regional benefits. The Rangeland Journal 19, 3-25.

Holmes, J., 2002: Diversity and change in Australia's rangelands: a post-productivist transition with a difference? Transactions of the Institute of British Geographers 27, 362-384.

Holmes, J., 2006: Impulses towards a multifunctional transition in rural Australia: gaps in the research agenda. Journal of Rural Studies 22, 142-160. 
Holmes, J.H. and Mott, J.J., 1993: Towards diversified use of Australia's savannas. In Young, M.D. and Solbrig, O.T. (eds.) The World's Savannas: Economic Driving Forces, Ecological Constraints and Policy Options for Sustainable Land Use. UNESCO Man and Biosphere Series, Paris, 283-317.

Howitt, R., 1993: Social impact assessment as 'applied peoples geography'. Australian Geographical Studies 31, $127-140$.

Industry Commission, 1998: A Full Repairing Lease: Inquiry into Sustainable Land Management. Commonwealth of Australia, Canberra.

Jackson, S., Stoeckl, N., Straton, A. and Stanley, O., 2008: The changing value of Australian tropical rivers. Geographical Research 46, 275-290.

Keon-Cohen, B., (ed.), 2001: Native Title in the New Millenium. Aboriginal Studies Press, Canberra.

Lane, M.B., 2002: Buying back and caring for country: institutional arrangements and possibilities for Indigenous lands management in Australia. Society and Natural Resources 15, 827-846.

Lane, M.B., 2005: The Indigenous Land Corporation's first land management policy: reconciling national policy with the contingencies of local context. Geographical Research 43, 224-237.

Ling, C., Handley, J. and Rodwell, J. 2007: Restructuring the post-industrial landscape: a multifunctional approach. Landscape Research 32, 285-309.

Lowe, P., Buller, H. and Ward, N., 2002: Setting the new agenda? British and French approaches to the second pillar of the Common Agricultural Policy. Journal of Rural Studies 18, 1-17.

Marsden, T., 1999: Rural futures: the consumption of the countryside and its regulation. Sociologia Ruralis 39, 501520.

McCarthy, J., 2005: Rural geography: multifunctional rural geographies - reactionary or radical? Progress in Human Geography 29, 773-782.

McGrath, A., 1987: Born in the Cattle. Allen and Unwin, Sydney.

Morton, S.R., 1993: Changing conservation perceptions in the Australian rangelands. The Rangeland Journal 15, $145-153$.

OECD 2001: Multifunctionality: towards an Analytical Framework. Organisation for Economic Cooperation and Development, Paris.

Perry, R.A., 1960: Pasture Lands of the Northern Territory, Australia. Land Research Series 5. C.S.I.R.O., Canberra.
Potter, C. and Burney, J., 2002: Agricultural multifunctionality in the WTO: legitimate non-trade concern or disguised protectionism? Journal of Rural Studies 18, 35-47.

Rogers, S.J., 1976: EDNA: Economic Development of Northern Australia. Bank of New South Wales Review 19 pp. 8-13.

The Rangeland Journal, 1994: Special Issue: Contemporary Explorations: Values, goals, Needs and Expectations of Rangeland Users. Vol. 16 (2).

The Rangeland Journal, 2003: Special Issue: Drivers of Change in the Rangelands. Vol. 25 (2).

't Mannetjee, L., Durand, M.R.E., Isbell, R.F. and Sturtz, J.D., 1976: Options for improved efficiency in the beef industry in non-arid tropical Australia. Tropical Grasslands 10, 151-164.

Tothill, J.C. and Mott, J.J., (eds.), 1985: Ecology and Management of the World's Savannas. Australian Academy of Science with C.A.B., Bucks.

Tropical Savannas Cooperative Research Centre, 2003: Strategy Statement 2003-2007. Darwin.

Williams, R.J., Hutley, L.B., Cook, G.D., Russell-Smith, J., Edwards, A. and Chen, X., 2004: Assessing the carbon sequestration potential of mesic savannas in the Northern Territory, Australia: approaches, uncertainties and potential impacts of fire. Functional Plant Biology 10, 415-422.

Wilson, G.A. 2001: From productivism to post-productivism and back again: exploring the (un)changed natural and mental landscapes of European agriculture. Transactions of the Institute of British Geographers 26, 77-102.

Wilson, G.A., 2007: Multifunctional Agriculture: a Transition Theory Perspective. CABI, Wallingford.

Woinarski, J., Mackey, B., Nix, H. and Traill, B., 2007: The Nature of Northern Australia. A.N.U. Press, Canberra.

Young, E., Ross, H., Johnston, J. and Kesteven, J. 1991: Caring for Country: Aborigines and Land Management. Australian National Parks and Wildlife Service, Canberra.

Young, E. and Ross, H., 1994: Using the Australian rangelands: 'insider' realities and 'outsider' perceptions. The Rangeland Journal 16, 184-197.

Young, M.D., 1981: Pressures for competing uses of the north west pastoral lands of Australia. Australian Rangeland Journal 3, 149-160.

Yu, P. and Yu, S., 2003: Impact of Tourism on the Gibb River Road: a Community Perspective. Tropical Savannas CRC, Darwin 